\title{
ARCHIWUM DZIEKAŃSKIE DEKANATU WAŁECKIEGO DO 1945 ROKU W ZASOBIE ARCHIWUM DIECEZJI KOSZALIŃSKO-KOLOBRZESKIEJ. INWENTARZ
}

\begin{abstract}
Streszczenie
W artykule przedstawiono zachowane archiwalia dziekańskie dotyczące dekanatu wałeckiego. Biskup poznański dla terytoriów zanoteckich utworzył w XIV wieku oficjalat kalisko-wałecki. W wyniku reformacji w połowie XVI wieku oficjalat przestał istnieć. W 1602 r. tereny pozostałe przy katolicyzmie włączono do utworzonego dekanatu czarnkowsko-wałeckiego. Po I rozbiorze Rzeczpospolitej na terenach ziemi wałeckiej reaktywowano oficjalat dla Prus Zachodnich. Pod koniec XVIII wieku wydzielono autonomiczny dekanat wałecki, który pokrywał się z terytorium powiatu poza Czaplinkiem z prowincji Pomorze. Początkowo składał się z 12 parafii i 34 kościołów filialnych. W XX wieku kilka filii stało się samodzielnymi ośrodkami duszpasterskimi. Zachowane archiwalia (159 poszytów) podzielono na dwie części: Generalia, dotyczące problematyki całego dekanatu, dzieląc je na dalsze serie, i Specjalia dotyczące poszczególnych parafii. Zachowane akta pochodzą od końca XVIII wieku do 1945 r.
\end{abstract}

Słowa kluczowe: dekanat wałecki; archidiecezja poznańska; Archiwum Archidiecezji Poznańskiej; archiwalia

* Ks. Tadeusz Ceynowa - dr historii Kościoła, adiunkt na Wydziale Teologicznym Uniwersytetu Szczecińskiego; dyrektor Archiwum Diecezji Koszalińsko-Kołobrzeskiej; dyrektor Biblioteki WSD w Koszalinie

e-mail: tceynowa@interia.pl

https://orcid.org/0000-0002-8105-8823 


\section{Wstęp}

Dzieje dekanatu wałeckiego były już wielokrotnie podnoszone w badaniach naukowych. Do tej pory opublikowano kilka prac dotyczących tej problematyki: Kulturkampf $w$ dekanacie wateckim (2003) ${ }^{1}$, Elżbietanki $w$ dekanacie wateckim w latach 1868-1920 (2004)2, Ziemia pogranicza. Dekanat watecki w latach 1821$1920(2004)^{3}$ i Źródta archiwalne do dziejów dekanatu wateckiego w latach 18211920 w zasobie Archiwum Archidiecezjalnego w Poznaniu (2008)4. Opracowanie stanowi zatem kolejne ogniwo w badaniach nad tym zagadnieniem. Staraniem autora jest prezentacja, uporządkowanie oraz charakterystyka stanu zachowanych materiałów archiwalnych wytworzonych przez kancelarię dekanatu wałeckiego. Opracowany inwentarz może stać się interesującym przewodnikiem dla historyków, którzy zamierzają podjąć dalsze szczegółowe badania nad przeszłością wspomnianego dekanatu.

Diecezja poznańska, obejmująca za czasów pierwszych Piastów całą Polskę, ulegała stopniowemu okrawaniu. Proces pomniejszania wpływów biskupa z Poznania rozpoczął się z chwilą ogłoszenia postanowień zjazdu gnieźnieńskiego. Powstały wówczas biskupstwa (Kraków, Wrocław i Kołobrzeg) wchodzące w skład metropolii gnieźnieńskiej, a następnie poprzez utworzenie diecezji w Lubuszu i Wolinie (przeniesionej później do Kamienia). Józef Nowacki, opisując północne granice diecezji poznańskiej, twierdził, że po upadku biskupstwa w Kołobrzegu pojawiła się konieczność podjęcia misji kościelnej na północ od Noteci i Warty.

W XIII wieku biskupi poznańscy sięgali swymi wpływami daleko na północ od linii Warty i Noteci, aż po obie strony rzeki Drawy ${ }^{5}$. Kraj ten tworzył osobną prepozyturę santocką, w której skład wchodziły m.in. Wałcz, Czaplinek i Kalisz Pomorski ${ }^{6}$.

Kiedy w 1296 r. Marchia zdobyła Santok, zlikwidowana została tamtejsza prepozytura. Jej uprawnienia oddano kolegiacie w Myśliborzu, zależnej od diecezji kamieńskiej. Od tego momentu przy Poznaniu pozostały tereny na wschód od Drawy ${ }^{7}$. Nie pomogły starania i zabiegi biskupów Andrzeja Zaremby i jego na-

${ }^{1}$ T. Ceynowa, Kulturkampf w dekanacie wateckim, ,Studia Koszalińsko-Kołobrzeskie”, (2003) nr 8, s. $165-178$.

${ }^{2}$ Tenże, Elżbietanki w dekanacie wateckim w latach 1868-1920, „Roczniki Teologiczne”, 51 (2004) nr 4, s. 129-147.

${ }^{3}$ Tenże, Ziemia pogranicza. Dekanat watecki w latach 1821-1920, Radom 2004.

${ }^{4}$ Tenże, Źródła archiwalne do dziejów dekanatu wateckiego w latach 1821-1920 w zasobie Archiwum Archidiecezjalnego w Poznaniu, w: Historia Ecclesiae in Pomerania. Księga jubileuszowa poświęcona ks. prof. zw. dr. hab. Lechowi Bończa-Bystrzyckiemu, red. Z. Lec, G. Wejman, Szczecin 2008, s. 247-269.

${ }^{5}$ J. Nowacki, Archidiecezja poznańska w granicach historycznych i jej ustrój, t. 2, Poznań 1964, s. 12-13.

${ }^{6}$ T. Silnicki, Z dziejów Kościoła w Polsce. Studia i szkice historyczne, Warszawa 1960, s. 199.

7 J. Walachowicz, Z problematyki kościelno-ustrojowej pogranicza diecezji poznańskiej, kamieńskiej i lubuskiej w średniowieczu, „Poznańskie Studia Teologiczne”, (1983) nr 4 s. 345; Nowacki, Archidiecezja poznańska, s. 16. 
stępców, podejmowane w Rzymie, aby odzyskać utraconą część diecezji ${ }^{8}$. W 1368 r. Polska odzyskała część terytorium zadrawskiego, przyznanego Poznaniowi. Jednakże ustalona granica państwowa nie zawsze pokrywała się z granicami diecezji, co rodziło w przyszłości problemy9.

\section{Dzieje ustrojowe twórcy zespołu}

Biskup poznański Andrzej Zaremba za namową metropolity gnieźnieńskiego Jakuba Świnki zdecydował się w 1298 r. na reformę archidiakonatu ${ }^{10}$. Z dotychczasowego (starego typu) utworzył trzy regionalne: większy (poznański), średni (śremski) i mniejszy (pszczewski). Ordynariusz określając granice poszczególnym archidiakonatom, wyłączył część diecezji na północ od Noteci, rezerwując ją dla czwartego - zanoteckiego. W 1349 r. pojawił się archidiakon Henryk, ustanowiony dla obszarów między Notecią i Drawą, który później pełnił inne funkcje ${ }^{11}$.

Zaremba zastrzegł sobie i swoim następcom mianowanie oraz instalowanie nowych archidiakonów. Określił im też dokładnie ich kompetencje: zarząd kościelny, prawo do wizytowania, ekskomunikowania, suspendowania, nakładania kar kościelnych oraz zwalniania od nich ${ }^{12}$.

Biskupom poznańskim nie udało się odzyskać terytoriów utraconych na zachód od Drawy. Dla ziem zanoteckich, które pozostały pod jurysdykcją Poznania, utworzono ostatecznie w XIV wieku oficjalat i dekanat, najpierw w Kaliszu Pomorskim $^{13}$, a następnie w Wałczu. Terytorium oficjalatu pokrywało się z dekanatem. Oficjałowie nowokaliscy posiadali każdorazowo władzę wikariusza generalnego i oficjała, ograniczoną obszarem dekanatu.

Sprawowanie funkcji w miejscu tak odległym od stolicy biskupiej oraz podległym władzy Nowej Marchii nie było zadaniem łatwym. Oficjałom potrzebne było do tego zezwolenie lub zapewnienie bezpieczeństwa jako obcokrajowcom. Z powyższych względów to mieszkańcy tych ziem obejmowali zarząd na północnych obrzeżach diecezji poznańskiej. Otrzymując uprawnienia sądowe i administracyjne, stawali się pełnomocnikami biskupa. Urząd oficjała sprawował proboszcz,

${ }^{8}$ Nowacki, Archidiecezja poznańska, s. 16. Silnicki (Z dziejów Kościoła, s. 199-200) podaje w wątpliwość gorliwość biskupów. O układzie granicznym z 1311 r. pomiędzy biskupem poznańskim a margrabiami brandenburskimi wspomina T. Jurek, Biskupstwo poznańskie $w$ wiekach średnich, Poznań 2018, s. 218-219.

${ }^{9}$ Jurek, Biskupstwo poznańskie, s. 219.

${ }^{10}$ Nowacki (Archidiecezja poznańska, s. 287) stwierdza, że przyczyną decyzji biskupa był ogrom pracy administracyjnej i sądowej na dużym obszarze, a także wzrost liczby parafii i zagrożenia zewnętrzne. Walachowicz z kolei (Z problematyki kościelno-ustrojowej, s. 347) zwraca szczególną uwagę na zagrożenia integralności terytorialnej.

${ }^{11}$ Nowacki, Archidiecezja poznańska, s. 292, 297; Silnicki, (Z dziejów Kościoła, s. 199) stwierdza, że nigdy nie doszło do utworzenia czwartego archidiakonatu.

12 Walachowicz, Z problematyki kościelno-ustrojowej, s. 347; Silnicki, Z dziejów Kościoła, s. 263-264.

${ }^{13}$ Nowacki (Archidiecezja poznańska, s. 239) podaje nazwy Kalisza Pomorskiego, spotykane w dokumentach: Kalisz (Calysz, Caliss, Callysch), Nowy Kalisz, Kaliszek. 
rezydujący w Kaliszu Pomorskim, pełniąc jednocześnie funkcję dziekana dla zanoteckiej części diecezji ${ }^{14}$.

Dla ziemi wałeckiej są do dyspozycji tylko dwa źródła z XIV wieku. Pierwsze pochodzi z 1337 r. i zawiera wykaz osadnictwa Nowej Marchii. Drugi dokument, autorstwa archidiakona zanoteckiego Henryka, nosi datę 30 maja 1349 r. Jest skierowany do biskupa Pałuki i mówi o dziesięcinach należnych jemu $\mathrm{z}$ tego terytorium. Na podstawie tylko tych dokumentów trudno jest wykazać dokładny rozkład ówczesnych ośrodków parafialnych.

Biorąc pod uwagę wyżej wspomniane dokumenty, a także protokoły z późniejszych wizytacji, Nowacki wylicza w dekanacie nowokaliskim następujące ośrodki parafialne: Barnimie, Biały Zdrój, Bobrowo, Borujsko, Bronikowo, Brzeźniak, Cybowo, Czaplinek, Człopa, Dębsko, Dobino, Giżyno, Gudowo, Hanki, Jastrowie, Jeziorki, Kalisz Pomorski, Kosobudy, Linowo, Lubiesz, Lubieszewo, Łowicz Wałecki, Marcinkowice, Marta (dziś Martew), Mielęcin, Mirosławiec, Nakielno, Niemcz, Orle, Osiek Drawski, Paźrzadło, Płociczno, Prusinowo Wałeckie, Rusinowo, Rzeczyca, Sadowo, Stara Korytnica, Stawno, Strzaliny, Suchowo, Suliszewo, Tuczno, Wałcz, Zdbice, Zdbowo, Żabin, Żabinek ${ }^{15}$.

Dekanat wałecki, będący jednocześnie oficjalatem foralnym, swym zasięgiem obejmował nie tylko tereny powiatu wałeckiego, sięgał również na ziemie Nowej Marchii. Dziekani-oficjałowie, mając szerokie uprawnienia każdorazowego ordynariusza, rozstrzygali wiele spraw osobiście. W latach 1395-1513 siedzibą oficjalatu były Kalisz Pomorski lub Wałcz. Nowacki, opierając się na aktach Archidiecezjalnego Archiwum Poznańskiego, wymienia następujących oficjałów:

1395

$1435-1456 \ldots$

$14 \ldots$

$1473-1494 \ldots$

$1504 \ldots$

1504

1506-1509

1509

1503
Henryk Pape, proboszcz w Nowym Kaliszu

Franciszek Sutczel, proboszcz nowokaliski

Piotr Clyekyemar

Jakub Niniński, pleban w Wałczu

Dawid, proboszcz nowokaliski

Michał Wolstcholth, pleban w Złocieńcu

Michał Westfal, pleban w Złocieńcu

Mikołaj Niniński, pleban wałecki

Mikołaj Hasse, proboszcz nowokaliski ${ }^{16}$.

Próby ratowania w czasie reformacji oficjalatu nowokalikiego podjął się bp

${ }^{14}$ Tamże, s. 240. Każdorazowy oficjał i dziekan dzięki zabezpieczeniu jego działania ze strony władców Polski mógł poruszać się swobodnie po terenach przygranicznych. Por. Walachowicz, Z problematyki kościelno-ustrojowej, s. 348.

${ }^{15}$ Nowacki, Archidiecezja poznańska, s. 386-397.

${ }^{16}$ Tamże, s. 241. T. Jurek (Biskupstwo poznańskie, s. 391) koryguje nieco tę listę. Henryka Pape uznaje za wikariusza. Pozostałych wymienia w następującej kolejności: 1435-1456 mgr Franciszek Sutzel prepozyt nowokaliski, 1473-1494 Jakub Niniński pleban w Wałczu, na przełomie XV i XVI wieku Piotr Clyekyennar, 1504 Dawid prepozyt nowokaliski, 1506-1509 mgr Michał Westfal pleban w Falkenbergu (dzisiaj Złocieniec), 1509 Mikołaj Niniński pleban w Wałczu, 1513 Mikołaj Hasse prepozyt nowokaliski. 
Sebastian Branicki, który przedstawił kapitule katedralnej w 1540 r. swego kandydata na oficjała. Miał nim być ówczesny proboszcz w Kaliszku ${ }^{17}$. Z całą pewnością oficjalat przestał istnieć jeszcze w pierwszej połowie XVI wieku. W wyniku reformacji stan posiadania Kościoła katolickiego uległ takiemu okrojeniu, że nawet odzyskiwane kościoły i dochody na przełomie XVI i XVII wieku nie umożliwiły powrotu do wcześniejszego stanu. Długo oczekiwana reorganizacja diecezji poznańskiej dokonała się dopiero na synodzie zwołanym przez biskupa Wawrzyńca Goślickiego w 1602 r. Utworzono 7 dekanatów, w tym czarnkowski, do którego włączono pozostałe przy katolicyzmie parafie dawnego dekanatu nowokaliskiego ${ }^{18}$.

Dawny oficjalat utracił bezpowrotnie ok. 27 parafii wokół Kalisza Pomorskiego i Złocieńca, należących do Nowej Marchii. Utracono kościoły w Mirosławcu i okolicach: Hankach, Próchnowie, Laskach, Kłosowie, Łowiczu, Sadowie i Płocicznie $^{19}$.

Rozprzestrzenianie się luteranizmu na terenie ziemi wałeckiej powstrzymali dopiero jezuici. Nowy zakon pojawił się na Wałecczyźnie w 1602 r. w Tucznie. Przyglądając się ich aktywności, Jan Gostomski, starosta wałecki, przeniósł jezuitów w 1618 r. do Wałcza ${ }^{20}$. Pierwszym dziekanem dekanatu czarnkowskiego został tamtejszy proboszcz Kasper Starościński ${ }^{21}$.

Zasięg terytorialny dekanatu określały wizytacje z lat: 1628, 1640, 1669, 1696, 1726-1728 i 1738.

${ }^{17}$ Biskup charakteryzował go jako męża statecznego i odpowiedniego.

${ }^{18}$ Nowacki Archidiecezja poznańska, s. 242 i 272.

${ }^{19}$ Tamże, s. 554. Nowacki podaje liczbę 71 kościołów - zarówno parafialnych, jak i filialnych utraconych w czasie reformacji w dawnym dekanacie nowokaliskim.

${ }^{20}$ Z. Boras, R. Walczak, A. Wędzki, Historia powiatu wateckiego w zarysie, Poznań 1961, s. 109-110; M. Rohwerder wydał w Kolonii w 1967 r. Historia residentiae Valcensis Societatis Jesu ab Anno Domini 1618. Kronikę prowadzili zakonnicy do 1773 r., do kasaty. L. Bąk, Dzieje szkoty średniej w Watczu,Od kolegium jezuickiego do liceum ogólnokształcacego (1665-1995), Inowrocław 1998; L. Bąk, Ziemia wałecka w dobie reformacji i kontrreformacji w XVI-XVIII w., Piła 1999, s. 289-388.

${ }^{21}$ Nowacki, Archidiecezja poznańska, s. 324. 


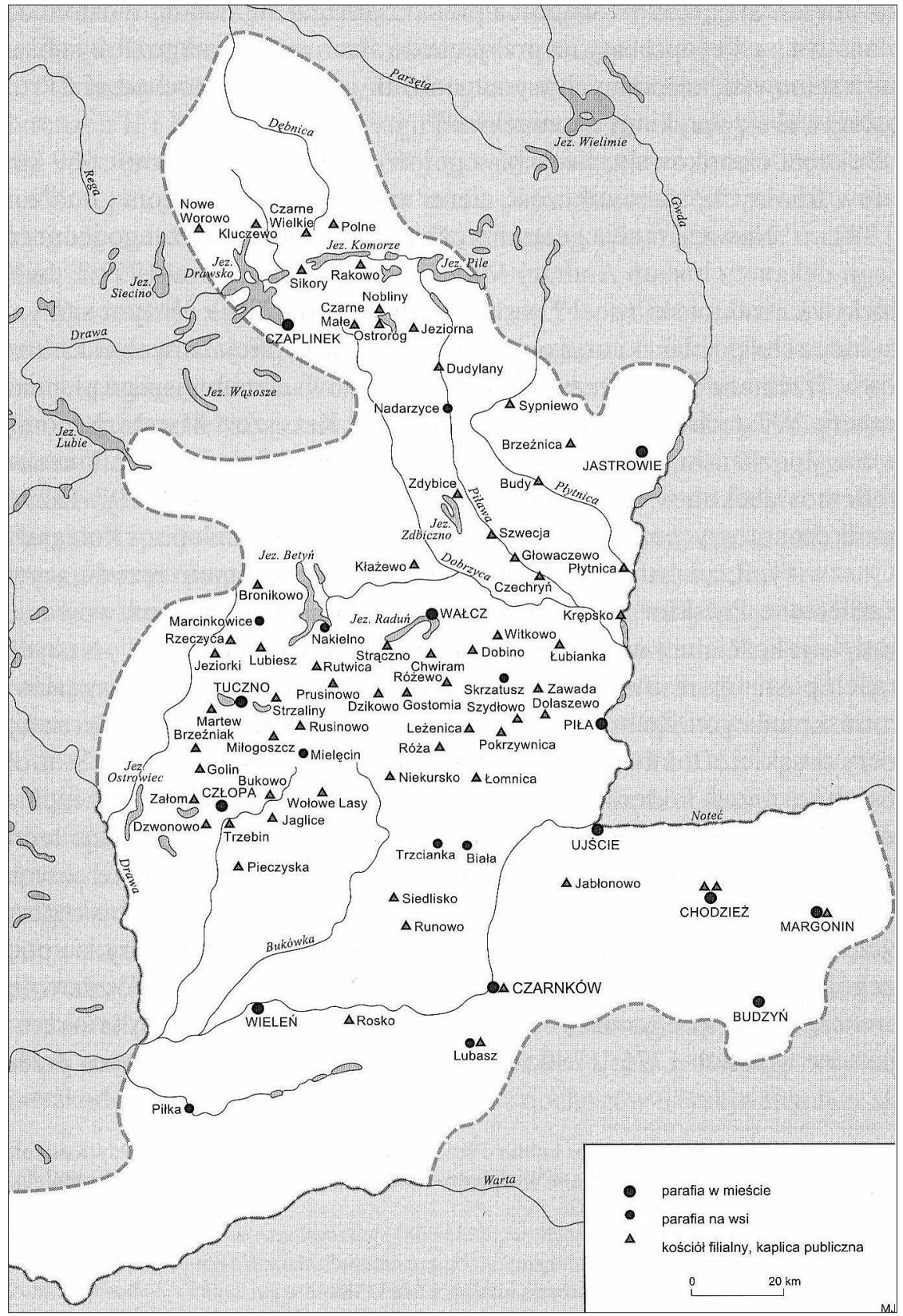

Mapa 1. Dekanat czarnkowski w połowie XVIII wieku

Na podstawie: S. Litak, Kościól laciński w Rzeczypospolitej około 1772 roku. Struktury administracyjne, Lublin 1996; S. Litak, Struktura terytorialna Kościoła łacińskiego w Polsce w 1772. Mapy, Lublin 1980, opracowanie kartograficzne Maria Juran. 
Po I rozbiorze dekanat czarnkowsko-wałecki wszedł w skład państwa pruskiego. Biskup poznański Andrzej Młodziejowski pod naciskiem zaborcy ustanowił na tym terenie oficjalat. Zmiana granic po 1815 r. ograniczyła jego zasięg tylko do dekanatu wałeckiego i nosił on nazwę Oficjalat Prus Zachodnich ${ }^{22}$. Z początku biskup, a po $1821 \mathrm{r}$. arcybiskup poznański mianował oficjałem zawsze jednego z proboszczów Wałecczyzny ${ }^{23}$. Każdorazowemu nominatowi ordynariusz powierzał władzę wikariusza generalnego - jednak ,w bardzo ścieśnionym zakresie"24. Oficjał wałecki miał prawo instytuowania kanonicznego na wszelkie beneficja. Sprawował także naczelny i nadzorczy zarząd majątkiem kościelnym, opiniował zawierane kontrakty dzierżawne, dotyczące zarówno ziemi parafialnej, jak $\mathrm{i}$ beneficjalnej. Akty nominacyjne wystawione przez ordynariusza oficjałom wałeckim wskazują, że uczestniczyli oni w niektórych uprawnieniach arcybiskupa z tytułu facultates quinquennales ${ }^{25}$. W 1863 r. arcybiskup Przyłuski zlecił konsystorzowi w Poznaniu przygotować nominację na oficjała dla ks. Habischa, wicedziekana i proboszcza w Wałczu, tej samej treści, jaką otrzymali wcześniej ks. Sydow i ks. Perzyński² ${ }^{26}$. Każdorazowy oficjał przeznaczony dla części archidiecezji leżącej na terenie Prus Zachodnich był zobowiązany składać coroczny raport ze swej sądowej i administracyjnej działalności ${ }^{27}$. Od końca XVIII wieku na Wałecczyźnie obowiązki swe sprawował osobno dziekan i oficjał. Sytuacja się nieco zmieniła, kiedy dziekan ks. Jan Krieger, pełniący funkcję od 1816 r., został mianowany członkiem kapituły chełmińskiej. Jego uroczysta instalacja na to stanowisko odbyła się przy okazji przeniesienia katedry do Pelplina 3 sierpnia $1824 \mathrm{r}^{28}$ Dwa lata później ks. Dalski, obarczony obowiązkami oficjała i dziekana, poprosił konsystorz, aby wakujący urząd dziekana powierzyć ks. M. Gramse, dotychczasowemu wicedziekanowi ze Skrzatusza ${ }^{29}$. Władze rejencyjne nie zatwierdziły wicedziekana na ten urząd, oficjał wałecki zaprezentował więc innych kandydatów: ks. Ch. Sydowa, komendarza z Czaplinka oraz ks. K. Busse z Marcinkowic ${ }^{30}$, ale

${ }^{22}$ B. Kumor, Ustrój i organizacja Kościoła polskiego w okresie niewoli narodowej 1772-1918, Kraków 1980, s. 178; Ceynowa, Ziemia pogranicza, s. 151.

${ }^{23}$ Archiwum Archidiecezji Poznańskiej (dalej: AAP), Akta Ordynariatu Arcybiskupiego od końca XVIII wieku (dalej: OA) X 156.

${ }^{24}$ Nowacki, Archidiecezja poznańska, s. 242.

${ }^{25}$ Por. Facultates, w: Encyklopedja kościelna podtug teologicznej encyklopedji Wetzera $i$ Weltego, z licznemi jej dopetnieniami, t. 5: Emanacja-Fürstenberg, red. M. Nowodworski, Warszawa 1874, s. 250-252.

${ }^{26}$ AAP, OA X 156, Polecenie arcybiskupa z 13 VII 1863 r. Ceynowa, Ziemia pogranicza, s. 152-153. Oficjałowie wałeccy otrzymywali od władz państwowych wynagrodzenie w wysokości 300 talarów, później 900 marek.

${ }^{27}$ AAP, Akta Konsystorza Generalnego, wzgl. Kurii Metropolitalnej od schyłku XVIII wieku (KA), 12004, Raport ks. Dalskiego z 15 VIII 1826 r. Oficjał poinformował ks. biskupa Wolickiego, administratora archidiecezji, że w pierwszym półroczu 1826 r. na terenie dekanatu nie rozpatrywał żadnych spraw sądowych.

${ }^{28}$ A. Mańkowski, Prałaci i kanonicy katedralni chetmińscy od założenia kapituly do naszych czasów, Toruń 1928, s. 99.

${ }^{29}$ AAP, KA 12004, Pismo ks. Dalskiego do konsystorza z 15 VIII 1826 r.

${ }^{30}$ Tamże. 
i oni nie zostali zaaprobowani przez Kwidzyn. Tak więc przez ostatnie lata urzędowania ks. Dalski wypełniał zarówno obowiązki oficjalskie, jak i dziekańskie na Wałecczyźnie. Było to jakby zapowiedzią późniejszej decyzji arcybiskupa poznańskiego, aby obie te funkcje pełniła jedna osoba. Plan ten miał z pewnością uniemożliwić władzom pruskim wywieranie nacisku na oficjała przy prezentowaniu kandydata na urząd dziekański w tej części archidiecezji. Taką praktykę stosowały władze kościelne od 1829 r., mianując kolejnych oficjałów-dziekanów dla Prus Zachodnich. Po autonomicznym wyborze kandydata konsystorz informował tylko władze rejencyjne w Kwidzynie o nowej nominacji ${ }^{31}$.

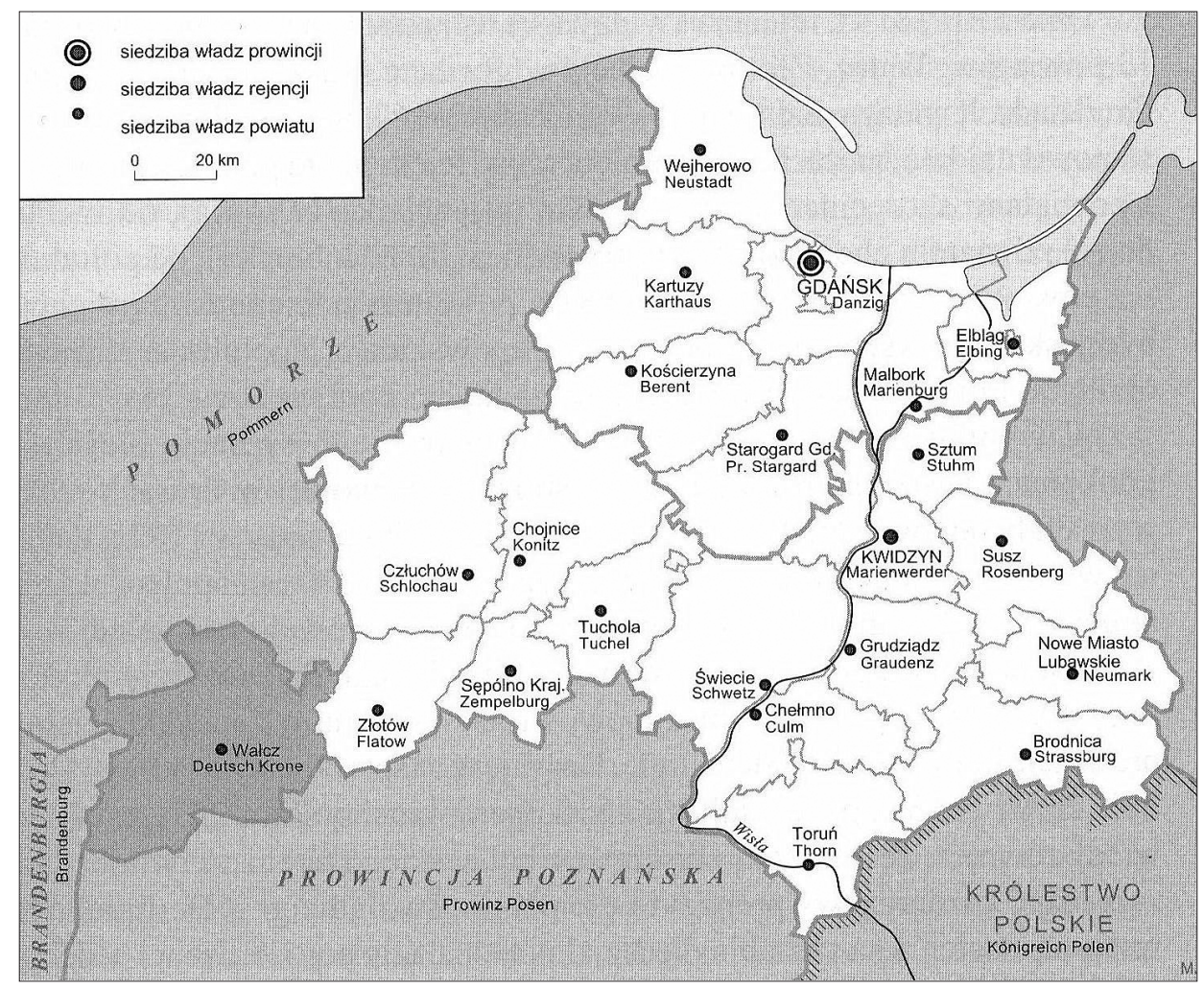

Mapa 2. Prusy Zachodnie (Westpreussen) - podział administracyjny prowincji z $1878 \mathrm{r}$. Na podstawie: Historia Pomorza, t. 4: 1850-1918, cz. 1: Ustrój, gospodarka, społeczeństwo, red. S. Salmonowicz, Toruń 2000, opracowanie kartograficzne Maria Juran.

${ }^{31}$ AAP, OA X 156, Pismo arcybiskupa Przyłuskiego do konsystorza z 21 I 1851 r. 
Po traktacie wersalskim dekanat wałecki pozostał na terenie Niemiec. Arcybiskup Edmund Dalbor dla terenów pozostałych poza kordonem granicznym, utworzył Administrację Arcybiskupią z siedzibą w Tucznie. Na jej czele stanął ks. prałat Robert Weimann. W 1923 r. papież Pius XI, dołączając dekanaty z diecezji chełmińskiej, erygował Administrację Apostolską w Tucznie, a następnie przeniósł jej siedzibę do Piły. Po konkordacie z Prusami w 1930 r. utworzono Wolną Prałaturę w Pile, włączając ją do metropolii wrocławskiej ${ }^{32}$.

Stolicą dekanatu był Wałcz, jednakże dziekani sprawujący tę funkcję nie zawsze tam rezydowali. Urząd dziekana w okresie, z którego zachowały się akta dziekańskie pełnili następujący duchowni: Joannes Cybort (1796-1816 Skrzatusz), Joannes Adalbert Krieger (1817-1824 Sypniewo), Józef Dalski, oficjał, pełnił obowiązki (1824-1829 Wałcz), Antoni Perzyński (1829-1850 Wałcz), Christian Sydow (1850-1863 Sypniewo), Joannes Habisch (1863-1872 Wałcz), Martin Friske (1872-1911 Sypniewo), Jakub Gerth (1911-1922 Marcinkowice) i Georg Krüger (1922-1944 Skrzatusz).

\section{Dzieje zespołu}

Ważnym zadaniem aktotwórcy było archiwizowanie dokumentów. Już synod z 1720 r. domagał się od dziekanów prowadzenia osobnego archiwum dekanalnego. Miały się $\mathrm{w}$ nim znajdować wszelkie dokumenty przechodzące przez ręce dziekana i sporządzane przez niego, a dotyczące całego spektrum spraw związanych z jego terenem ${ }^{33}$. Nominat przejmował sporządzone przez poprzednika akta i dołączał do nich własne. Spis dokonany przez dziekana Habischa 1 lipca $1863 \mathrm{r}$. rzuca światło na ogrom pracy wykonywanej przez pośrednika między arcybiskupem a duchowieństwem parafialnym. Wykaz przejętych akt po ks. Sydowie wyszczególniał następujące zagadnienia: zarządzenia konsystorskie (3 wol.), instrukcje co do zarządzania parafią (1 wol.), kongregacje dekanalne (1 wol.), spisy lagatów (1 wol.), poświęcenia (1 wol.), zmiany wyznania (1 wol.), zbiory praw (1 wol.), instytut dla ociemniałych w Królewcu (1 wol.), opłaty za miejsca w kościele (1 wol.), zmarli na cholerę (1 wol.), ubezpieczenia kościołów od pożaru ( 1 wol.), sprawy budowlane ( 1 wol.), wizytacje parafialne (5 wol.), kazania z oka-

${ }^{32}$ L. Petzelt, Die Errichtung der Erzbischöflichen Delegatur und die Anfänge der Apostolischen Administratur Tütz, w: Die Apostolische Administratur Schneidemühl. Ein Buch für das katholische Volk, red. F. Westpfahl, Schneidemühl 1928, s. 12-15; B. Kumor, Granice metropolii i diecezji polskich (968-1939), „Archiwa, Biblioteki i Muzea Kościelne”, 21 (1972) s. 370; Erich Klitsche, Die Bulle de salute animarum vom Jahre 1821 und die Entwicklung der kirchlichen Verhältnisse im Osten Deutschlands bis auf unsere Zeit, w: Die Apostolische Administratur Schneidemühl, s. 46-47; E. Gatz, Schneidemühl, w: Lexikon für Theologie und Kirche, Bd. 9, red. M. Buchberger, W. Kasper, Freiburg im Breisgau 2000, szp. 189-190; R. Prejs, Prałatura pilska w świetle schematyzmu z 1940 r., „Roczniki Teologiczne”, 55 (2008) nr 4, s. 36-37. Tam też literatura na temat prałatury pilskiej. Autor przy opracowaniu artykułu korzystał z kopii tego schematyzmu znajdującej się w Archiwum Diecezji Koszalińsko-Kołobrzeskiej. T. Ceynowa, Materiały Archiwum Diecezji Koszalińsko-Kołobrzeskiej w Koszalinie dotyczące kościelnych dziejów Pity, „Studia Koszalińsko-Kołobrzeskie", (2019) nr 26, s. 251-252.

${ }^{33}$ K. Wasiak, Dziekani archidiecezji poznańskiej, Lublin 1964 (mps), s. 29. 
zji ślubów ( 2 wol.), małżeństwa mieszane ( 1 wol.), dyspensy małżeńskie ( 2 wol.), fundusze z kolekty (1 wol.), wytyczne do sporządzania etatów (1 wol.), spisy cathedraticum (2 wol.), rekolekcje (1 wol.), szkoły parafialne (1 wol.), sprawa Czerskiego (1 wol.), akta denuncjacyjne ( 1 wol.), listy konduity ( 2 wol.), progimnazjum w Wałczu (1 wol.) oraz sprawy dotyczące poszczególnych parafii dekanatu (23 wol.) oprócz Sypniewa (parafia dziekańska) ${ }^{34}$. Powyższy spis pozwala ustalić stan zachowania ówczesnego zespołu z połowy XIX wieku. Akta dziekańskie zmieniały miejsce pobytu. Były przenoszone na miejsce pracy duszpasterskiej nowo mianowanego dziekana. Większość opracowanego zespołu została początkowo przekazana z parafii Marcinkowice do Tymczasowego Archiwum w Kołobrzegu, skąd przejęto je do archiwum diecezjalnego w Koszalinie. Pozostałe jednostki (sygn. 9, 28-32/2, 49-50, 62, 67-68, 74 i 142) zostały wyodrębnione z akt parafii w Skrzatuszu ${ }^{35}$, gdzie urzędował ostatni dziekan do 1944 r. Można wyciągnąć z tego wniosek, że ks. G. Krüger nie przejął wszystkich akt z Marcinkowic po zmarłym w 1922 r. poprzedniku.

\section{Charakterystyka i metoda porządkowania zespołu archiwalnego}

Tytuł. Zespołowi nadano tytuł Akta Dziekańskie Dekanatu Wałeckiego. Niemiecka tytulatura brzmiała Acta des Dekanats Deutch Krone. Chronologia. Najstarsze zachowane akta pochodzą z 1784 r. Większość została wytworzona w XIX i XX w. Poza dziennikiem urzędowym prałatury pilskiej (Amtliche Bekanntmachungen der Freien Prälatur Schneidemühl) nie zachowały się archiwalia z czasów II wojny światowej.

Terytorium. Akta dotyczą terytorium dekanatu wałeckiego, który odłączono od dekanatu czarnkowskiego w 1772 r. Rozgraniczenie dokonywało się stopniowo. Początkowo Piłę zaliczano do dekanatu wałeckiego, a Człopę do czarnkowskiego. Od 1814 r. terytorium było niezmienne aż do zakończenia II wojny światowej. Jedenaście parafii: Człopa (Schloppe), Jastrowie (Jastrow), Łubianka (Lebehnke), Marcinkowice (Marzdorf), Mielęcin (Mellentin), Nakielno (Klein Nakel), Róża Wielka (Rose), Skrzatusz (Schrotz), Sypniewo (Zippnow), Tuczno (Tuetz) i Wałcz (Deutch Krone) leżały w powiecie wałeckim, rejencji kwidzyńskiej w Prowincji Prusy Zachodnie, tylko Czaplinek (Tempelburg) leżał w powiecie szczecineckim, rejencji koszalińskiej w Prowincji Pomorze. W okresie międzywojennym dekanat wałecki (poza Czaplinkiem) znajdował się w rejencji pilskiej do 1938 r. Po zmianach administracyjnych rejencję pilską przemianowano na rejencję Marchia Graniczna Poznań Prusy Zachodnie i włączono do Prowincji Pomorze. W dwudziestoleciu międzywojennym w dekanacie powstały dwie nowe parafie: Szwecja (Freundenfier 1922) i Rzeczyca (Knakendorf 1923) i cztery ośrodki duszpasterskie (Lokalvikarie): Dobino (Breitenstein 1927), Dzikowo (Dyck 1923), Niekursko (Niekosken 1927) i Nadarzyce (Rederitz 1917).

${ }^{34}$ AAP, KA II 56/2. Po ks. Perzyńskim przejęto 34 teczki.

${ }^{35}$ Akta parafii w Skrzatuszu do r. 1945 zostały przejęte bezpośrednio do Archiwum Diecezji Koszalińsko-Kołobrzeskiej w 2005 r. 
Warto zaznaczyć, że dziekani wałeccy wizytowali trzy filie parafii pilskiej, które znajdowały się na terenie powiatu wałeckiego ${ }^{36}$.

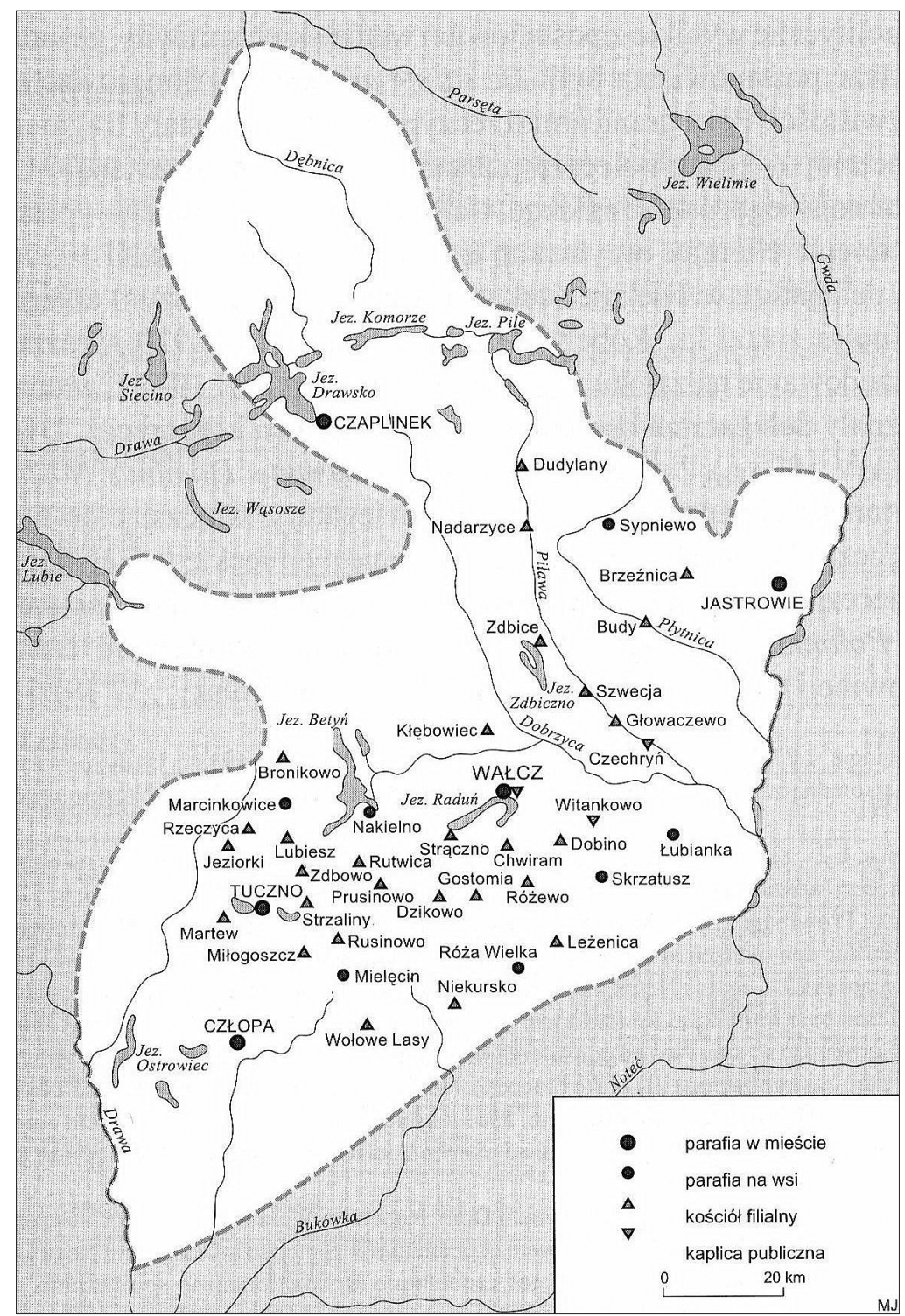

Mapa 3. Dekanat wałecki w drugiej połowie XIX wieku

Na podstawie materiałów autora, opracowanie kartograficzne Maria Juran.

${ }^{36}$ Dziekani wałeccy domagali się za to specjalnego wynagrodzenia. W pracach kancelaryjnych urzędu dziekańskiego pomocą służył notariusz. Najczęściej spisywał on protokoły kongregacji dekanalnych, wizytacji dekanalnych czy dokumenty dotyczące wprowadzenia na urząd. Biblioteką dekanalną zarządzał specjalnie mianowany bibliotekarz. Ceynowa, Ziemia pogranicza, s. 160. 
Typ kancelarii. Akta prowadzono systemem kancelarii spraw typowym dla kancelarii pruskiej.

Stan zachowania. Zespół akt dziekańskich dekanatu wałeckiego składa się ze 161 jednostek archiwalnych (1,5 mb.). Stan zachowania materiałów archiwalnych jest na ogół dobry. Zespół nie jest kompletny. W zinwentaryzowanym zespole brakuje niektórych jednostek wspomnianych przez ks. Habischa w 1863 r. Najliczniej zachowały się akta XIX-wieczne, spisywane najczęściej na dobrym jakościowo papierze. Sprzyjały temu też częste kontrole władz świeckich i konsystorskich. Większość akt ma postać typowego poszytu stosowanego w czasach pruskich. Większość poszytów posiada ręczne napisy odnośnie do zawartości. Nie spotkano żadnych wypustek z nazwami jednostek. W okresie międzywojennym akta umieszczano w skoroszytach lub teczkach. Spotyka się korespondencję pisaną na maszynie. Przeważa język niemiecki, zwłaszcza pod koniec XIX i na początku XX wieku. Wcześniej zdarzają się pisma w języku polskim i łacińskim.

Metoda porządkowania. Zachowany stan archiwaliów dziekańskich uniemożliwia odtworzenie wcześniejszego układu akt w registraturze. W trakcie inwentaryzacji zespołowi nadano strukturę własną, kierując się kryterium treści i zasadą schematyczno-rzeczową. Zespół podzielono na dwie części: Generalia, traktujące o problematyce całego dekanatu, dzieląc je na dalsze serie, i Specjalia dotyczące poszczególnych ośrodków duszpasterskich funkcjonujących na przestrzeni lat w dekanacie. Teczki i poszyty otrzymały zastępcze tytuły, tam gdzie ich nie było, karty inwentarzowe, daty skrajne, sygnaturę i paginację.

\section{Zawartość zespołu}

Na treść składają się akta ogólne dotyczące dekanatu wałeckiego. W trakcie porządkowania nadano im następujący schemat: I. Dziekan i księża w dekanacie (sygn. 1-9); II. Rozporządzenia władz kościelnych i państwowych (sygn. 10-32); III. Finanse (sygn. 33-51); IV. Fundacje (sygn. 52); V. Wizytacje dziekańskie (sygn. 53-63); VI. Kongregacje dekanalne (sygn. 64-68); VII. Statystyka (sygn. 6974); VIII. Stowarzyszenia i szpitale (sygn. 75-77); IX. Problemy duszpasterskie (sygn. 78); X. Szkoły (sygn.79-96); XI. Sprawy sporne (sygn. 97-100); XII. Konwersje (sygn. 101); XIII. Korespondencja (sygn. 102-109) i XIV. Varia (sygn. 110-118). W części drugiej zawarte są archiwalia odnoszące się do działalności poszczególnych parafii ${ }^{37}$.

Mimo braków zachowane akta prezentują z pewnością dużą wartość naukową dla dziejów lokalnego Kościoła, jakim jest dekanat. Dają możliwość poznania historii diecezji poznańskiej czy prałatury pilskiej. Tym bardziej że akta tej ostatniej zostały doszczętnie zniszczone podczas działań wojennych w 1945 r.

${ }^{37} \mathrm{~W}$ tej części widać najbardziej braki w zachowanej dokumentacji. 


\section{AKTA DZIEKAŃSKIE DEKANATU WAŁECKIEGO}

\section{GENERALIA}

\section{Dziekan i księża w dekanacie}

1. Konduiten, 1826.

Poszyt, j. niemiecki, ss. 9.

2. Acta die Introduction des Herrn Probstes Golz in Behle betreffend, 1833.

Poszyt, j. niemiecki, ss. 2.

3. Acta person [...] Habisch, 1833-1837.

Poszyt, j. niemiecki, ss. 7.

4. [Nominacje], 1839-1916.

Teczka, luzy, j. niemiecki, j. łaciński, j. polski, ss. 11.

5. Actenstück betreffend die Konduiten=Liste von der Geistlichkeit des Dt. Croner Dekanats, 1849-1862. Poszyt, j. niemiecki, ss. 183.

6. Actenstueck betreffend das Verfahren in Kirchen und Pfarrbausachen im Dt. Croner Decanats, 1857.

Poszyt, j. niemiecki, ss. 8.

7. [Rekolekcje duchowieństwa dekanalnego], 1857-1873. Poszyt, j. niemiecki, ss. 49.

8. Acta betreffend die Dekanats-Verwaltung des Officials Habisch, 1863-1872. Poszyt, j. niemiecki, ss. 83.

9. [Duchowieństwo dekanalne], 1913-1944. Teczka, luzy, j. niemiecki, ss. 374.

\section{Rozporządzenia władz kościelnych i państwowych}

10. [Rozporządzenia], 1788-1907. Teczka, luzy, j. niemiecki, j. łaciński, j. polski, ss. 155.

11. Rescripte, 1793-1805. Poszyt, j. niemiecki, j. polski, ss. 50.

12. Acta u. Protocolle, 1798. Poszyt, j. niemiecki, ss. 150.

13. Rescripte der Königlichen Regierung von Pommern vom Jahr 1812. Poszyt, j. niemiecki, ss. 91.

14. Verordnung über den Landsturm [Friedrich Wilhelm], 1813. Teczka, luzy, j. niemiecki, ss. 7.

15. Rescripte der Königliche Regierung von Pommern vom Jahr 1812-1813. Poszyt, j. niemiecki, ss. 81.

16. Sammlung der Königlichen Regierungs Rescripten von Pommern der Parochie Tempelburgischen Angelegenheiten für das Jahr, [1813] 1816. Poszyt, j. niemiecki, ss. 190.

17. Acta die eingegangenen Rescripte von der Special Commision. Separations Angeleigenheiten, 1833-1837.

Poszyt, j. niemiecki, ss. 133.

18. [Rozporządzenia], 1835-1862.

Teczka, luzy, j. niemiecki, j. łaciński, j. polski, ss. 13. 
19. Circularia, 1836-1837.

Poszyt, j. niemiecki, j. łaciński, j. polski, ss. 40.

20. Verfügungen des Erzbischöflichen General Konsistorium zu Posen vom J. 1838-1839.

Poszyt, j. niemiecki, j. polski, ss. 13.

21. [Rozporządzenia], 1841-1844.

Teczka, luzy, j. niemiecki, j. łaciński, j. polski, ss. 147.

22. Circularia vom Jahre 1845-1847.

Teczka, luzy, j. niemiecki, j. polski, ss. 94.

23. Acta den katholischen Decanats Dt. Crone betreffend die Consistorial Verfugungen pro 1845, 1846, 1847 und 1848, [1836].

Poszyt, luzy, j. niemiecki, j. polski, ss. 73.

24. Acta der kathol. Decanats Dt. Crone betreffend die Circulair Verfugungen des Dt. Croner Dekanats, 1846-1848.

Poszyt, j. niemiecki, ss. 91.

25. [Rozporządzenia], 1848-1849.

Teczka, luzy, j. niemiecki, ss. 28.

26. [Kopie rozporządzeń władz świeckich i kościelnych], 1854.

Teczka, luzy, j. niemiecki, ss. 23.

27. [Rozporządzenia], 1858.

Teczka, luzy, j. niemiecki, ss. 6.

28. Acta betr. Dekankongregationen, 1866-1912.

Poszyt, j. łaciński, ss. 226.

29. Amtliche Bekanntmachungen für der Erzbischöfliche Delegatur 1920 (nr 1), 1921(nry 2-9), 1922(nry 10-17), 1923(nry 18-20).

Teczka, luzy, j. niemiecki.

30. Amtliche Bekanntmachungen der Apostolischen Administratur 1923(nry 2124), 1924(nry 25-30), 1925(nry 31-37), 1956(nry 38-48), 1927(nry 49-60), 1928(nry 61-72), 1929(nry 73-84), 1930(nry 85-92).

Teczka, luzy, j. niemiecki.

31. Amtliche Bekanntmachungen der Freien Prälatur Schneidemühl, 1930(nry 1-3), 1931(nry 1-12), 1932(nry 1-12), 1933(nry 1-12), 1934(nry 1-12).

Teczka, luzy, j. niemiecki.

32. Amtliche Bekanntmachungen der Freien Prälatur Schneidemühl 1935(nry 1-13), 1936(nry 1-13), 1937(nry 1-13).

Teczka, luzy, j. niemiecki.

32/1. Amtliche Bekanntmachungen der Freien Prälatur Schneidemühl 1938(nry 1-13), 1939(nry 1-14), 1940(nry 1-11).

Teczka, luzy, j. niemiecki

32/2. Amtliche Bekanntmachungen der Freien Prälatur Schneidemühl 1941(nry 1-12), 1942(nry 1-12), 1943(nry 1-12), 1944(nry 1-12).

Teczka, luzy, j. niemiecki.

\section{Finanse, świadczenia}

33. Berichte betreffend die Einsendung der Gelder zum Aufbau der katholischen Kirche und des Pfarrhauses zu Holten, 1803.

Poszyt, j. niemiecki, ss. 31. 
34. Kirchenrechnungen [...] Dt. Cronische Synode von Jahr 1816. Poszyt, j. niemiecki, ss. 43.

35. Jahres Rechnung der römisch katholischen Kirchen Kasse zu Dt. Crone pro 1825.

Poszyt, j. niemiecki, ss. 30.

36. Actenstück über eingekommenen und Abgeführte Archi=kathedralstauer und dem Dt. Croner Dekanat Angelegt vom Prodecan Probst Sydow in Zippnow von 1 Juli 1850, 1850-1855.

Poszyt, j. niemiecki, ss. 107.

37. Actenstück betreffend Kirchenkassen-Rechnung-Angelegenheit des Dt. Croner Decnats, 1851-1873.

Poszyt, j. niemiecki, ss. 25.

38. Actenstück über die eingekommenen und abgeführte Kathedral=Stuer von den Pfarreien des Dt. Kroner Dekanats, 1855-1869.

Poszyt, j. niemiecki, j. polski, ss. 160.

39. [Kolekty], 1857.

Teczka, luzy, j. niemiecki, ss. 7.

40. Actenstück über eingekommenen und abge [...] Kollekten Gelder aus dem Dt. Croner Dekanate Angelegt vom Official und Dekan Sydow in Zippnow im Monate März 1857, 1857-1872.

Poszyt, j. niemiecki, ss. 192.

41. Actenstück betreffend die milden Beiträge für den h. Vater Papst Pius IX, 1860-1872, [Stowarzyszenie św. Stanisława z dekanatu wałeckiego].

Poszyt, luzy, j. niemiecki, ss. 84 .

42. Collectengelder, 1886-1893.

Poszyt, j. niemiecki, ss. 217.

43. Kirchenkassen-Revision von 1890-1894.

Poszyt, j. niemiecki, j. polski, ss. 328.

44. Kirchenkassen-Revision II, 1897.

Poszyt, j. niemiecki, ss. 266.

45. [Kolekty], 1900-1901.

Teczka, luzy, j. niemiecki, ss. 15.

46. Collectegelder IV, 1901-1906.

Poszyt, j. niemiecki, ss. 210.

47. Acta betreffend Geldangeleheiten, 1911-1916.

Poszyt, j. niemiecki, ss. 164.

48. [Kolekty], 1913-1914.

Teczka, luzy, j. niemiecki, ss. 23.

49. Emeritensteuer, 1915-1922.

Teczka, luzy, j. niemiecki, ss. 58 .

50. [Kolekty w dekanacie wałeckim], 1915-1930.

Teczka, luzy, j. niemiecki, ss. 166.

51. [Kolekty], 1916-1917.

Teczka, luzy, j. niemiecki, ss. 12. 


\section{Fundacje}

52. Dekanat Fundationes, 1911-1944. Teczka, luzy, j. niemiecki, ss. 182.

\section{Wizytacje dziekańskie}

53. [Wizytacja w Ujściu ks. Dalskiego], 1799. Poszyt, j. łaciński, ss. 28.

54. Kirchen Visitations Recesse der Posenschen [...] Dioeces von Jahr 1812. Poszyt, j. niemiecki, ss. 24.

55. Kirchen Visitations Recesse der [...] Posenschen Dioeces von Jahr 1812. Poszyt, j. niemiecki, ss. 31.

56. Kirchen=Visitations=Verhandlung, 1832. Teczka, luzy, j. niemiecki, ss. 52.

57. Kirchen=Visitations=Verhandlung, 1855. Teczka, luzy, j. niemiecki, ss. 44.

58. Kirchen=Visitations=Verhandlung, 1856. Teczka, luzy, j. niemiecki, ss. 64 .

59. Kirchen=Visitations Verhandlungen im Deutsch Croner Dekanat, 1856-1857. Poszyt, j. niemiecki, ss. 157.

60. Acta enthalten Kirchenvisitationen des Dekanats Deutsch-Crone vom Jahr 1865. Poszyt, j. niemiecki, ss. 156.

61. Acta betreffend die abgehalten Kirchenvisitationen 1872-1901. Poszyt, j. laciński, j. niemiecki, j. polski, 1872-1901, ss. 193.

62. [Rewizja kas parafialnych przez dziekana]. Teczka, luzy, j. niemiecki, 1909-1933, j. niemiecki, ss. 162.

63. Visitations $=$ Verhandlung, 1941-1944. Teczka, luzy, j. niemiecki, ss. 168.

\section{Kongregacje dekanalne}

64. Aktenstück über abgehaltene Kongregationen des Dt. Croner Dekanats, 1851. Poszyt, j. niemiecki, ss. 6.

65. [Kongregacje dekanalne], 1852-1870. Teczka, luzy, j. niemiecki, ss. 84.

66. Acta Congregationum Decanalium, 1872-1911. Poszyt, j. niemiecki, ss. 400.

67. Acta betreffend Congregationen, 1911-1917. Poszyt, j. niemiecki, ss. 218.

68. [Kongregacje dekanalne], 1919-1938. Teczka, luzy, j. niemiecki, ss. 393.

\section{Statystyka dekanalna}

69. Concept=Buch pro 1831, 1831-1833. Poszyt, j. niemiecki, j. łaciński, j. polski, ss. 94.

70. Actenstück betreffend die Selenzahl der Dt. Krone Dekanats, 1850-1858. Poszyt, j. niemiecki, ss. 130. 
71. Actenstück betreffend die speciall fugirenden Geistlichen bei den Pfarr = oder Kommendariat Kirche des Deutsch-Kroner - Dekanats und die summarische Seelenzahl [...], 1857-1872.

Poszyt, j. niemiecki, ss. 79.

72. [Liczba chrztów i ślubów w parafiach dekanatu], 1861-1862.

Teczka, luzy, j. niemiecki, ss. 13.

73. Acta betreffend den Klerus und die Seelenzahl des Dekanats Dt. Krone, 18721910. Poszyt, j. niemiecki, ss. 290.

74. Kirchliche Statistik, 1918-1942.

Teczka, luzy, j. niemiecki, ss. 86.

\section{Stowarzyszenia i szpitale}

75. [Szpital w Wałczu], 1821. Teczka, luzy, j. niemiecki, ss. 2.

76. Stowarzyszenie św. Josephata, 1862.

Teczka, luzy, j. niemiecki, ss. 4.

77. Unio Cleri pro Missionibus Priester-Missionsbund in den Ländern Dtsch. Zunge, 1924-1937. [Dotyczy całej prałatury].

Teczka, luzy, j. niemiecki, j. łaciński, ss. 168.

\section{Problemy duszpasterskie}

78. Fürsorger, 1917-1922. Teczka, j. niemiecki, ss. 53.

\section{Szkoly}

79. [Dokumenty dotyczące rezydencji jezuitów w Wałczu], 1661-1738. Poszyt, j. niemiecki, j. łaciński, j. polski, ss. 51.

80. Gimnazjum wałeckie, 1784-1802.

Poszyt, j. niemiecki, ss. 22.

81. Gimnazjum w Wałczu, 1785-1808.

Teczka, luzy, j. niemiecki, ss. 15.

82. Acta die Schule zu Rosenfelde, 1791-1801.

Poszyt, j. niemiecki, ss. 17.

83. Schul Tabelle, [1794] 1808.

Poszyt, j. niemiecki, ss. 33.

84. [Kapitały dotyczące gimnazjów], brak daty.

Teczka, luzy, j. niemiecki, ss. 6.

85. Gimnazjum w Wałczu, 1799-1805.

Teczka, luzy, j. niemiecki, ss. 15.

86. Besoldungs Etat für das Jesuiter Gymnasium zu Deutsch Crone, 1802.

Teczka, luzy, j. niemiecki, ss. 2.

87. Acta Gymnasium Valcense concernentia, 1804-1805.

Poszyt, j. niemiecki, ss. 114.

88. Königliche Westpreuisischen Regierungs Rescripte die Leistungs Vergutungs Sache vom Jesuiter Gymnasien Vorwerk betreffend von Jahr 1811-1812.

Poszyt, j. niemiecki, ss. 31.

89. Schultabelle von dem Konigl. Dorf Wittkow zur Parochie Schrotz gehörig von Jahr 1821-1822.

Poszyt, j. niemiecki, ss. 7. 
90. Tabelle von der Dorf Schule Rederitz vom Jahr 1821-1822.

Teczka, luzy, j. niemiecki, ss. 6.

91. [Szkoła w Człopie], 1822.

Teczka, luzy, j. niemiecki, ss. 4.

92. [Szkoły w dekanacie], 1822.

Teczka, luzy, j. niemiecki, ss. 9.

93. [Sprawy szkolne], 1822-1831.

Teczka, luzy, j. niemiecki, ss. 76.

94. Musterungs=Tabelle der kath. Schulen in der D. Cronische Synode, 18241825.

Poszyt, j. niemiecki, ss. 36.

95. Schul Akten, 1851-1898.

Poszyt, j. niemiecki, ss. 305.

96. Lehrer-Seminar Dt. Crone, 1902-1907.

Poszyt, j. niemiecki, ss. 132.

XI. Sprawy sporne

97. Aktenstück in Denunziations und Untersuchungsachen [...], 1855-1856.

Poszyt, j. niemiecki, ss. 21.

98. Acta der Konversionen, 1865-1870.

Teczka, luzy, j. niemiecki, ss. 5.

99. [ks. Carol Wurst], 1886-1887.

Teczka, luzy, j. niemiecki, ss. 12.

100. Beschwerden gegen Ewart Verwaltung durch Pf. Schade (Freudenfier), 1916-1919.

Teczka, luzy, j. niemiecki, ss. 169.

XII. Konwersje

103. Actenstück im Betreffe der Übertritte aus dem evangelischen und jüdischen Glaubensbekenntnisse zur katholischen Kirche, 1849-1854.

Poszyt, j. niemiecki, ss. 24.

\section{Korespondencja}

102. [List z 1774 r. do Leopolda Hibnera prokuratora Prowincji Prusy Zachodnie], 1774.

Teczka, luzy, j. niemiecki, ss. 2.

103. [Korespondencja], 1805-1806.

Poszyt, j. niemiecki, ss. 31.

104. Sammlung der vom Probst Gramse eingegangenen Zuschriften, 1823-1828.

Poszyt, j. niemiecki, ss. 81.

105. [Korespondencja], 1830.

Poszyt, j. niemiecki, ss. 13.

106. [Korespondencja, obsada parafii w Nakielnie], 1837-1847. Poszyt, j. niemiecki, j. polski, ss. 48.

107. Acta betreffend Verfügungen und Aufträge des Officials, 1850-1858. Poszyt, j. niemiecki, ss. 202.

108. [Korespondencja różna], 1905-1916.

Teczka, luzy, j. niemiecki, ss. 42. 
109. Sprawy dekanatu wałeckiego - korespondencja z władzami w Poznaniu, Tucznie i Pile, 1914-1937.

Teczka, luzy, j. niemiecki, ss. 257.

\section{Varia}

110. Varia, 1780-1840.

Teczka, luzy, j. niemiecki, j. łaciński, j. polski, ss. 88 .

111. Varia, 1822-1861. Teczka, luzy, j. niemiecki, j. łaciński, ss. 64.

112. Varia,1825-1828. [o prowadzeniu ksiąg metrykalnych]. Teczka, luzy, j. niemiecki, ss. 22.

113. Korespondencja, składki katedralne, podziękowania, sprawy dot. szkoły, 1829-1835.

Poszyt, j. niemiecki, j. łaciński, j. polski, ss. 311.

114. Acta verschiedene Verhandlungen betreffend, 1830-1840.

Poszyt, j. niemiecki, ss. 17.

115. Varia [Sprawy wojskowe], 1838, 1915.

Teczka, luzy, j. niemiecki, ss. 14.

116. Varia, 1841-1915. Teczka, j. niemiecki, ss. 125.

117. Varia, 1892-1903.

Poszyt, j. niemiecki, j. polski, ss. 326.

118. Varia, 1931-1937.

Teczka, luzy, j. niemiecki, ss. 64.

\section{SPECJALIA}

\section{Czaplinek (Tempelburg)}

119. Conceptbuch betreffend in Tempelburgischen Angelegenheiten vom 4 Juni 1817, 1817-1818.

Poszyt, j. niemiecki, ss. 93.

120. Concept Buch der Tempelburgischen Pfarr Angelegenheiten vom 30 Mai 1826, 1826-1827.

Poszyt, j. niemiecki, ss. 38 .

121. [Korespondencja], 1849.

Teczka, luzy, j. niemiecki, ss. 2.

122. [Korespondencja], 1912-1916.

Teczka, luzy, j. niemiecki, ss. 11.

\section{Człopa (Schloppe)}

123. Populations=Listen aus dem Czarnickauer Decanat Officials (tylko Człopa z dekanatu wałeckiego), 1803.

Poszyt, j. niemiecki, ss. 25.

124. Beläge zur Jahres Rechnung der katholischen Kirchenkasse zu Schloppe in Regierung Bezirk Marienwerder Kreis Dt. Crone pro 1833.

Poszyt, j. niemiecki, ss. 25. 
125. Beläge zur Jahres Rechnung der katholischen Kirchenkasse zu Schloppe in Regierung Bezirk Marienwerder Kreis Dt. Crone pro 1854.

Poszyt, j. niemiecki, ss. 24.

126. Jahres Rechnung der katholischen Kirchenkasse zu Schloppe in Regierungsbezirk Marienwerder Kreis Dt. Crone pro Anno 1854.

Poszyt, j. niemiecki, ss. 13.

III. Dobino (Breitenstein)

127. Jährliche Kirchenrechnung der zur Parochie Dt. Crone belegen Filial Kirche zu Breitenstein, 1810-1813.

Poszyt, j. niemiecki, ss. 28.

IV. Jastrowie (Jastrow)

128. Nachweisung der übergebenen Kirche und Schuldokumente a) den [...] Schulke; b) an die Kreis-Justic-Commision zu Jastrow, 1825-1826.

Poszyt, j. niemiecki, ss. 23.

\section{Pokrzywnica (Krummflies)}

129. Actenstück in der Kirchenkassen=Rechnungsangelegenheit der Pfarre Schneidemühle und zwar von Krummflies, 1850. Poszyt, j. niemiecki, ss. 6.

130. Jahresrechnung 1855.

Teczka, luzy, j. niemiecki, ss. 12.

131. Summarischer extract aus der für des Jahr 1856 gelegten Kirchenrechnung der Filiale Krummflies.

Poszyt, j. niemiecki, ss. 11.

\section{Róża Wielka (Rose)}

132. Wizytacja kościoła w Róży, 1787. Poszyt, j. łaciński, ss. 13.

133. [Varia], 1826-1851.

Teczka, luzy, j. niemiecki, ss. 16.

134. Extrakt z rachunku kasy kościoła filialnego w Dykowie, 1835. Teczka, luzy, j. polski, ss. 2.

135. Verzeichnis des Kirchenvermögens der kathol. Kirche zu Rose, 1851. Teczka, j. niemiecki, ss. 17.

136. Verzeichnis des Kirchenvermögens von der kathol. Kirche zu Rose, 1859. Teczka, j. niemiecki, ss. 5 .

137. [Przejęcie parafii i inne dokumenty], 1859-1886. Teczka, luzy, j. niemiecki, ss. 33.

VII. Skrzatusz (Schrotz)

138. Tabele der Confirmanden führ Jahr 1821 in der Pfarre Schrotz, 1821-1822. Teczka, luzy, j. niemiecki, ss. 2.

139. [Korespondencja], 1916. Teczka, luzy, ss. 5.

\section{Sypniewo (Zippnow)}

140. Sammlung der eingangenen [...] von Probste Sydow zu Zippnow von Jahr 1829-1832.

Poszyt, j. niemiecki, ss. 33. 
141. [Varia], 1829-1886.

Teczka, luzy, j. niemiecki, ss. 118.

142. [Brzeźnica], 1911-1935.

Teczka, luzy, j. niemiecki, ss.16.

143. Korespondencja w sprawie tworzenia lokalnych wikariatów w Nadarzycach i Szwecji, 1912-1914.

Teczka, luzy, j. niemiecki, ss. 118.

\section{Tuczno (Tuetz)}

144. Acta betreffend die Besetzung des Beneficium zu Tuetz, [1798] 1800-1828. Poszyt, j. niemiecki, j. łaciński, ss. 52.

145. Ablösung einer 40 Talerrente (Lukowskische Stiftung) zum einen Grundstück in Behle, 1868-1873.

Poszyt, j. niemiecki, ss. 81.

146. Recess über die Ablösung der auf dem parzelirten Grundstücke No 87 zu Behle Kreis Czernikau, 1872-1873.

Poszyt, j. niemiecki, ss. 67.

147. Stiftungen, 1926-1940.

Teczka, luzy, j. niemiecki, ss. 36.

\section{Wałcz (Deutsch Krone)}

148. Nachweisung der a) für die Kirche zu Dt. Crone, b) für den Parochus, c) für die Marianische Capelle, d) für die St. Barbara Capelle, 1821. Poszyt, j. niemiecki, ss. 14.

149. Sammlung von Eingaben und Antwortung die Einzeichnung der Missalien aus der Stadt Dt. Crone betreffend vom Jahr 1825.

Poszyt, j. niemiecki, ss. 11.

150. Einnahme und Ausgabe Beläge zur römisch kath. Kirchenkassen Rechnung der Stadt Dt. Croner pro 1827, 1827-1831.

Poszyt, j. niemiecki, ss. 54.

151. Nachweisung der in der Regulirungs und Gemeinheits Aufhebungs Angelegenheit von Breitenstein Kreis Dt. Crone aufgelaufenen Kosten, 1828. Poszyt, j. niemiecki, ss. 7.

152. Acta betreffend die von der katholischen Pfarre zu Dt. Crone zum [...] der Stadt Dt. Crone abgetretenen Ländereien, 1832-1836.

Poszyt, j. niemiecki, j. polski, ss. 53.

153. [Folwark proboszczowski], 1834. Poszyt, j. niemiecki, j. polski, ss. 15.

154. Acta Generalia der katholischen Kirchen Kasse Dt. Crone, 1835. Poszyt, j. niemiecki, ss. 20.

155. [Dokumenty dekanalne], 1835-1887.

Poszyt, j. niemiecki, j. polski, ss. 100.

156. Beantwortung der Notaten über die Kassenrechnung der katholische Pfarrkirche zu Dt. Crone pro 1839, 1839-1840.

Poszyt, j. niemiecki, ss. 6.

157. Beantwortung der Notaten über die Kassenrechnung der katholischen Pfarrkirche zu Dt. Crone pro 1841.

Poszyt, j. niemiecki, ss. 10. 
158. Beantwortung der Notaten über die Kassen=Rechnung der katholischen Pfarrkirche zu Dt. Crone pro 1842.

Teczka, luzy, ss. 6.

159. Jahres=Rechnung der katholischen Kirchen=Kasse zu Dt. Crone Regierungs=Department Marienwerder pro 1843.

Poszyt, j. niemiecki, ss. 30.

\section{REFERENCES / BIBLIOGRAFIA}

\section{Źródla archiwalne}

Archiwum Archidiecezji Poznańskiej (AAP)

Akta Konsystorza Generalnego, wzgl. Kurii Metropolitalnej od schyłku XVIII wieku, 12004.

Akta Konsystorza Generalnego, wzgl. Kurii Metropolitalnej od schyłku XVIII wieku, II $56 / 2$.

Akta Ordynariatu Arcybiskupiego od końca XVIII wieku, X 156.

\section{Opracowania}

Bąk Ludwik, Dzieje szkoły średniej w Wałczu. Od kolegium jezuickiego do liceum ogólnokształcacego (1665-1995), Inowrocław 1998.

Bąk Ludwik, Ziemia watecka $w$ dobie reformacji i kontrreformacji w XVI-XVIII w., Piła 1999.

Boras Zygmunt, Walczak Ryszard, Wędzki Andrzej, Historia powiatu wateckiego w zarysie, Poznań 1961.

Ceynowa Tadeusz, Elżbietanki w dekanacie wateckim w latach 1868-1920, „Roczniki Teologiczne", 51 (2004) nr 4, s. 129-147.

Ceynowa Tadeusz, Kulturkampf $w$ dekanacie wateckim, „Studia Koszalińsko-Kołobrzeskie", (2003) nr 8, s. 165-178.

Ceynowa Tadeusz, Materiały Archiwum Diecezji Koszalińsko-Kołobrzeskiej w Koszalinie dotyczace kościelnych dziejów Piły, „Studia Koszalińsko-Kołobrzeskie”, (2019) nr 26, s. 249-266.

Ceynowa Tadeusz, Ziemia pogranicza. Dekanat watecki w latach 1821-1920, Radom 2004.

Ceynowa Tadeusz, Źródła archiwalne do dziejów dekanatu wateckiego w latach 18211920 w zasobie Archiwum Archidiecezjalnego w Poznaniu, w: Historia Ecclesiae in Pomerania. Ksiega jubileuszowa poświęcona ks. prof. zw. dr. hab. Lechowi Bończa -Bystrzyckiemu, red. Z. Lec, G. Wejman, Szczecin 2008, s. 247-269.

Facultates, w: Encyklopedja kościelna podtug teologicznej encyklopedji Wetzera $i$ Weltego, z licznemi jej dopetnieniami, t. 5: Emanacja-Fürstenberg, red. Michał Nowodworski, Warszawa 1874, s. 250-252.

Gatz Erwin, Schneidemühl, w: Lexikon für Theologie und Kirche, Bd. 9, red. M. Buchberger, W. Kasper, Freiburg im Breisgau 2000, szp. 189-190.

Historia Pomorza, t. 4: 1850-1918, cz. 1: Ustrój, gospodarka, spoleczeństwo, red. S. Salmonowicz, Torun 2000. 
Historia residentiae Valcensis Societatis Jesu ab Anno Domini 1618, red. M. Rohwerder, Kolonia 1967.

Jurek Tomasz, Biskupstwo poznańskie w wiekach średnich, Poznań 2018.

Klitsche Erich, Die Bulle de salute animarum vom Jahre 1821 und die Entwicklung der kirchlichen Verhältnisse im Osten Deutschlands bis auf unsere Zeit, w: Die Apostolische Administratur Schneidemühl. Ein Buch für das katholische Volk, red. F. Westpfahl, Schneidemühl 1928, s. 46-47.

Kumor Bolesław, Granice metropolii i diecezji polskich (968-1939), „Archiwa, Biblioteki i Muzea Kościelne”, 21 (1972) s. 309-404.

Kumor Bolesław, Ustrój i organizacja Kościoła polskiego w okresie niewoli narodowej 1772-1918, Kraków 1980.

Litak Stanisław, Kościół łaciński w Rzeczypospolitej około 1772 roku. Struktury administracyjne, Lublin 1996.

Litak Stanisław, Struktura terytorialna Kościoła łacińskiego w Polsce w 1772. Mapy, Lublin 1980.

Mańkowski Alfons, Prałaci i kanonicy katedralni chetmińscy od założenia kapituły do naszych czasów, Toruń 1928.

Nowacki Józef, Archidiecezja poznańska w granicach historycznych i jej ustrój, t. 2, Poznań 1964.

Petzelt Ludwig, Die Errichtung der Erzbischöflichen Delegatur und die Anfänge der Apostolischen Administratur Tütz, w: Die Apostolische Administratur Schneidemühl. Ein Buch für das katholische Volk, red. F. Westpfahl, Schneidemühl 1928, s. 12-15.

Prejs Roland, Prałatura pilska w świetle schematyzmu z 1940 r., „Roczniki Teologiczne”, 55 (2008) nr 4, s. 36-37.

Silnicki Tadeusz, Z dziejów Kościoła w Polsce. Studia i szkice historyczne, Warszawa 1960.

Walachowicz Jerzy, Z problematyki kościelno-ustrojowej pogranicza diecezji poznańskiej, kamieńskiej i lubuskiej wśredniowieczu, „Poznańskie Studia Teologiczne”, (1983) nr 4, s. 309-314.

Wasiak K., Dziekani archidiecezji poznańskiej, Lublin 1964, (mps). 


\title{
THE DEAN'S ARCHIVE OF THE WALCZ (WALCZ) DEANERY UNTIL 1945 IN THE RESOURCES OF THE ARCHIVES OF THE KOSZALIN-KOLOBRZEG (KOLOBRZEG) DIOCESE. INVENTORY
}

\begin{abstract}
The article presents the preserved dean's archives concerning the Walcz (Wałcz) deanery. In the $14^{\text {th }}$ century, the bishop of Poznan (Poznań) created the Kalisz-Walcz (Wałcz) official office for the territories behind the Notec (Noteć). As a result of the Reformation, in the mid- $16^{\text {th }}$ century the official office ceased to exist. In 1602, the areas remaining under Catholic Church administration were incorporated into the newly created Czarnkow (Czarnków)-Walcz (Wałcz) deanery. After the First Partition, the official office for West Prussia was reactivated in the area of Walcz (Wałcz). At the end of the $18^{\text {th }}$ century, the autonomous deanery of Walcz (Wałcz) was established, which coincided with the territory of the poviat, except for Czaplinek, of the Pomeranian province. Initially, it consisted of 12 parishes and 34 branch churches. In the $20^{\text {th }}$ century, several branches became independent pastoral centres. The preserved archives (159 notebooks) were divided into two parts: Generalia, concerning the issues of the entire deanery, divided into further series, and Specialties concerning individual parishes. The preserved files date from the end of the $18^{\text {th }}$ century until 1945.
\end{abstract}

Keywords: the Walcz (Wałcz) Decanate; dean; Archdiocese of Poznan (Poznań); Archives of the Koszalin-Kolobrzeg (Kołobrzeg) Diocese; archives 